\title{
"One Belt and One Road" Strategy and the Economic Development Study under the New Normal in China
}

\author{
Le-Zhou LYU ${ }^{1, a}$ \\ ${ }^{1}$ Vanke Meisha Academy, D1203, Hengyubincheng phase 1, Zhongxin Road, Nanshan \\ District \\ aLvlz2019@outlook.com
}

Keywords: "One Belt and One Road"; the new normal; Upgrading of industrial structure; Global value chain.

\begin{abstract}
One Belt and One Road is new opening strategy to promote sustainable economic development under the new normal in China. It embodies the Chinese wisdom of top-level design of "promoting reform through opening up, promoting development through reform and promoting transformation through development". This paper considers that opening up to the outside world is an opportunity for domestic development, which releases space for domestic development and provides a channel for releasing excess capacity and a driving force for optimizing industrial structure. Domestic reform is the basis of opening up to the outside world. In particular, the establishment of market mechanism and institutional rules is fundamental to ensuring the quality of opening up to the outside world. In the implementation of the strategy, we should build the national value chain and the china-led global value chain through the balanced development of the domestic regional economy and the efforts of international regional economic integration and the optimization and upgrading of the industrial structure, so as to enable the Chinese economy to participate in the international economy and enhance the competitiveness of the Chinese economy.
\end{abstract}

\section{Introduction}

The "One Belt And One Road" strategy is a new type of open development strategy adopted to continuously promote the steady development of Chinese economy in the postcrisis era, after China has entered into middle income level and under the condition that the international and domestic economic situation have new changes. From the perspective of opening up to the outside world, under the international economic situation of sluggish global economic recovery and rising regionalism, how to actively participate in and lead regional economic integration through "going out" has become an urgent matter to absorb excess domestic capacity and facilitate the upgrading of industrial structure. From the perspective of domestic reform, how to promote the transformation of development mode, seek the sustained impetus of economic growth, and avoid falling into the "middle-income trap" through comprehensively deepening reform under the "new normal" of the economy has become the focus of development. Therefore, although “One Belt and One Road” is an open direction, its essence is a comprehensive development strategy of "promoting reform through opening up, promoting development through reform and promoting transformation through development". Therefore, the understanding of "One Belt And One Road" should not only be limited to an open international perspective, nor should it adhere to the traditional experience of development, but should combine the two organically. We need to integrate inclusive development, economic globalization and regional economic integration. We will combine 
knowledge accumulation, technological innovation, market rules and institutional building. We will integrate the conformity, participation and domination of international economic relations into the process of deep participation in the international economy. In the implementation of the strategy, we should increase the pressure and impetus for the domestic economic development and transformation through the comprehensive opening up to the outside world, and work hard on market rules, system construction and management experience. We should give full play to the decisive role of the market in the allocation of resources by comprehensively deepening domestic reform. Through a competitive enterprise system, industrial structure and domestically led global value chain, we strongly support the overall quality improvement of opening up economy to the outside world.

\section{“One Belt and One Road" is an Inevitable Choice for China to Implement an Open Economy}

\section{The Deep Participation of the International Capital Movement and Chinese Economic Globalization}

Generally speaking, capital internationalization and international transfer between industries are the basic rules of capital movement. On the one hand, through the international flow of capital, we can overcome the declining trend of average profits of domestic capital and obtain high returns. On the other hand, through capital investment, the industrial transfer in the world is driven, making the industrial production settled in the world, and forming the economic globalization. From the individual point of view of capital movement, the international movement of a country's capital firstly conducts capital accumulation through capital import. The country has changed from a capital - scarce country to a capital - rich one. Capital export is then followed (see table 1). The international flow of capital not only provides the way for export countries to absorb the excess capacity, but also provides the exogenous power for import countries to accumulate capital [1]. In this process, capital is not only the flow of money, but also the integration of resource elements, including technology, management and system. It allocates factors of production worldwide through industrial transfer. The development of China's reform and opening up over the past 35 years is a good illustration of this. At present, China has become the world's second largest economy, the largest trading exporter and the third largest foreign investor. Relative to the excess capacity, it has put forward the capital export and international industrial transfer requirements.

However, in the current international economic situation, Chinese foreign investment is facing a severe dilemma. On the one hand, industrial competition not only faces the oppression competition of developed countries, the exclusive competition of emerging economies, but also the challenge competition of emerging developing economies. On the other hand, taking the economic crisis and the third industrial revolution as an opportunity, the "re-industrialization" and the return of high-end industries in developed countries make the international industrial transfer present the dual closed structure of high-end industrial value chain circulating within developed countries, and the low-end industrial value chain circulating within the post-developed countries [2]. Therefore, it is decided that Chinese foreign investment and industrial transfer must take both high-end and low-end industries into account. On the one hand, by "reverse investment" from developed countries, the high-end development of the industry is sought. On the other hand, some China-led global value chains are constructed through the transfer of domestic excess capacity [1] through investment in 
sub-developing countries. “One Belt And One Road” is an export-oriented development strategy proposed in response to this problem. Through in-depth cooperation with surrounding countries along the belt and road, China can better integrate into the global economy from the aspects of international market, resource allocation and industrial transfer. For example, countries and regions along the routes of southeast Asia, Africa and eastern Europe face difficulties in developing their economies, funding shortages and domestic employment. Chinese investment in these regions will help host countries to solve demand and employment and promote their industrialization. At the same time, it can realize the external extension of the domestic industry, promote the adjustment and upgrading of the industrial structure, and achieve a win-win situation.

Table 1. The periodical characters of international capital movement with developing countries as the orientation.

\begin{tabular}{|c|c|c|c|}
\hline Stage & $\begin{array}{l}\text { Capital import(introduction of } \\
\text { foreign capital) }\end{array}$ & $\begin{array}{c}\text { Capital accumulation(factor } \\
\text { agglomeration) }\end{array}$ & Capital export(foreign investment) \\
\hline $\begin{array}{l}\text { Main } \\
\text { forms }\end{array}$ & Foreign direct investment(FDI) & $\begin{array}{l}\text { Embed the low-end global value } \\
\text { chain and implement OEM } \\
\text { according to the comparative } \\
\text { advantage }\end{array}$ & $\begin{array}{l}\text { 'Backward outsourcing" (for } \\
\text { developed countries) and foreign } \\
\text { direct investment (for emerging } \\
\text { developing countries) }\end{array}$ \\
\hline $\begin{array}{c}\text { Basic } \\
\text { functio } \\
\text { ns }\end{array}$ & $\begin{array}{l}\text { Make up and replace capital } \\
\text { original accumulation, solve } \\
\text { capital extremely scarce } \\
\text { bottleneck }\end{array}$ & $\begin{array}{l}\text { tegrate into global production, improve } \\
\text { factor efficiency, accelerate capital } \\
\text { accumulation, form domestic market, } \\
\text { promote industry rapidly, and implement } \\
\text { economic take-off }\end{array}$ & $\begin{array}{l}\text { Export excess production } \\
\text { capacity, improve capital returns, } \\
\text { construct domestic industrial and } \\
\text { technological system, and } \\
\text { promote the high-level } \\
\text { development of economy through } \\
\text { internal and external interaction }\end{array}$ \\
\hline $\begin{array}{l}\text { Develo } \\
\text { pment } \\
\text { contrib } \\
\text { ution }\end{array}$ & $\begin{array}{l}\text { The start of industrialization: it } \\
\text { provides the first impetus for the } \\
\text { utilization of domestic low-end } \\
\text { factors, provides the premise for } \\
\text { the development of comparative } \\
\text { advantage of factor endowment, } \\
\text { and participates in global } \\
\text { production. }\end{array}$ & $\begin{array}{l}\text { Extensive industrial production: } \\
\text { diversified industrial structure, } \\
\text { expansion of industrial production } \\
\text { scale, rapid accumulation of capital } \\
\text { and rapid increase of production } \\
\text { capacity }\end{array}$ & $\begin{array}{l}\text { peepening industrial production: } \\
\text { technological advances and } \\
\text { knowledge accumulation nurture } \\
\text { and allocate advanced production } \\
\text { factors globally, lead some value } \\
\text { chains around the world }\end{array}$ \\
\hline $\begin{array}{l}\text { Upgra } \\
\text { de } \\
\text { require } \\
\text { ments }\end{array}$ & $\begin{array}{l}\text { Industrialization strategy: it is } \\
\text { necessary to take advantage of } \\
\text { comparative advantages to } \\
\text { participate in international } \\
\text { division of labour and } \\
\text { implement the industrialization } \\
\text { strategy according to the } \\
\text { characteristics of national factor } \\
\text { endowment. Only by } \\
\text { implementing the } \\
\text { industrialization strategy can we } \\
\text { solve the problem of poverty } \\
\text { fundamentally }\end{array}$ & $\begin{array}{l}\text { Industrialization upgrading: the } \\
\text { expansion of industrialization in the } \\
\text { domestic scope is the result of the } \\
\text { global value chain leading the } \\
\text { capital movement, which is a } \\
\text { passive growth. Technological } \\
\text { progress, human management } \\
\text { improvement, and realing } \\
\text { upgrading can get rid of the low-end } \\
\text { lock of the value chain and realize } \\
\text { the endogenous development of the } \\
\text { domestic economy }\end{array}$ & $\begin{array}{l}\text { Globalization strategy: low - end } \\
\text { overcapacity and insufficient } \\
\text { market demand, industrial } \\
\text { upgrading block, relative surplus } \\
\text { of capital. Participate in } \\
\text { international competition and } \\
\text { promote the formation and } \\
\text { development of advanced } \\
\text { production factors. Improve the } \\
\text { internal and external market rules } \\
\text { and optimize the economic } \\
\text { structure }\end{array}$ \\
\hline
\end{tabular}

Note: domestic low-end factors refer to the cheap labour, land and ecological environment in developing countries. Advanced production factors refer to the core technologies, high-end talents, management experience and system rules that multinational companies rely on to distribute production around the world.

Material source: the author organised according to relevant literature. 


\section{The Bottleneck of Economic Growth and the Low-End Break out of Global Value Chain}

The modern social and economic development, whether it's the growth of quantity, or quality improvement, is reflected in the optimization and upgrading of industrial structure, and the seniroization of knowledge accumulation, technological advancements and factors related to it. The international division of labour within products and the production layout led by multinational corporations have deepened the economic globalization and the economic dependence of all countries. No economy can decouple from the international capital movement and industrial transfer that take the global value chain as the carrier, and the resulting complex economic relationships of production, trade, investment and services. The global value chain changes the connotation of economic competitiveness, making the competition of various economies more focused on the cross-border production of enterprises and the core competence at the process and task level [3]. If the industrial upgrading of the traditional mode is mainly represented by the upgrading and replacement of a country in different periods, different industries and departments, then the industrial upgrading of the global value chain is mainly represented by the upgrading and expansion of the process, product, function or value chain within the industrial sector [4]. The degree of a country's participation in the global value chain and its leading status have become an important embodiment of its economic quality. So, under the trend of economic globalization, the economic development of all countries in the first step is to participate in the global market, utilize the global capital, manpower, knowledge and technology, to integrate into the global value chain, create value for the value chain and get their own share [5].

The rapid development of China's reform and opening up over the past 35 years is due to its successful integration into the global value chain through export-oriented economy. At the same time, Chinese industrial development has been confused by the "low-end lock" of the value chain and economic growth has entered the bottleneck because it has not been able to achieve the high-end climb of the value chain through technological innovation and the development of the service industry Many scholars have thoroughly analysed this problem and put forward corresponding policy ideas for this problem. For example, Liu zhibiao [6] proposed the strategic concept of Chinese economic globalization 1.0 to 2.0 in a series of articles. He believes that while actively participating in the global value chain, we should lose no time in constructing the national value chain, actively integrate into the global innovation chain and eventually move to the China-led global value chain. Zhang youwen[7] also believes that China's globalization is entering the second stage from the first stage. The embedded global value chain is only the result of passive acceptance of global production in multinational companies under the open condition, and it is the factor agglomeration of the first stage. The second stage should cultivate advanced elements such as technology, management and talents, from passive growth to active development. Lu jinyong et al. [8] believe that after reform and opening up, China has experienced three stages: foreign trade, foreign investment and foreign direct investment. At present, foreign investment is implementing the strategy of "global value chain promotion", and participating in global production in a diversified and three-dimensional manner. Zhang Ming and Liang hongji [2] believe that the third industrial revolution is changing the basis of the global industrial chain from value concept and technological means. To ensure the effective growth of Chinese industrial security and wealth, it is necessary to enhance its competitiveness in the global value chain. The views of the above scholars all indicate that, under the global value chain 
production model, it has become an urgent task for China in participating in the global economy to implement the low-end breakout and build a China-led global value chain.

Generally speaking, developing countries can realize the upgrading of the value chain through "backward outsourcing" or acquisition of high-value-added production links. However, the implementation of this strategy requires the support of enterprises through the domestic "system effect" and "knowledge accumulation" [5], which is not as easy as OEM. Therefore, the key to constructing a country-led global value chain is the investment and experience accumulation in knowledge accumulation, technological innovation, industrial standards, trade rules and regional coordination. We can reduce the time it takes for knowledge accumulation and technological innovation by "reverse investing" in the developed world. However, only through the integration of international industrial transfer and regional economic integration can these tacit knowledge be realized gradually in practice. Therefore, it is necessary to give domestic multinational corporations a period of preparation for overseas study of rules and system supply. "One Belt And One Road" is just such a realistic strategic choice, which provides a feasible way for Chinese enterprises to deeply participate in the international economic operation.

\section{In-Depth Adjustment of International Economic Relations and Its Active Response}

With the deepening of globalization, especially after the 2008 financial crisis, new changes have taken place in international trade and investment rules. First, the service trade and investment agreement have become the core contents of the new round of trade negotiations and rule making. Second, a new free-trade agreement with higher standards will lead the new rules for global trade. Third, the WTO multilateral trading system will be increasingly marginalized [9].

The deep adjustment of international trade rules is the result of the evolution of international division of labour. Production segmentation and production accumulation coexist, and value chain segmentation and supply chain shaping form the division of labour and trade within products. "Globalization" and "fragmentation" of manufacturing industry have become the important characteristics and evolution trend of global division of labour and production system. The global value chain transforms the traditional "trade in goods" into "trade in tasks" and "made in a country" into "made in the world". Service outsourcing enables the previously non-tradable service sector to enter the field of international trade and investment [10].This makes the boundary between trade and domestic policies more ambiguous, and pushes the new trade rules from the traditional "goods trade tariffs, non-tariff barriers, trade remedies" to the core content of "competition policy, intellectual property protection, investment and capital flow"[3]

With the new changes in international economic relations, on the one hand, the "negative list" of international trade and investment is replacing the "positive list" implemented by the WTO. On the other hand, the new round of economic globalization promoted by the developed countries, led by the United States, is vigorously promoting a series of bilateral and multilateral negotiations. It is trying to build new international trade rules based on TISA, TPP and TTIP to block emerging economies such as China. It is under such circumstances that "One Belt and One Road" actively responds to the deep adjustment of international economic relations in the new era. First, by implementing the "One Belt And One Road" strategy, we will build a new pattern of all-round opening up and a new framework for international cooperation, implement more proactive opening policies, expand the space for China-EU cooperation, deepen cooperation with central Asia, southeast Asia, South Asia and 
other neighbouring countries, and deepen economic and trade exchanges between China and Arab countries [11], so as to meet the challenges brought by the United States. Secondly, the implementation of "One Belt And One Road" strategy is conducive to China's conformity, participation and leadership of international economic relations rules. "Negative list" is the product of regional economic integration. With the rise of regionalism, regional economy will play an important role in the integration of international economic relations in the future. China lacks this cooperation platform in its participation in the foreign economy. "One Belt And One Road" strategy is essentially an effort of regional economic integration. It explores emerging regional cooperation mechanisms, which are linked by transportation channels, based on interconnection, and characterized by multiple cooperation mechanisms and aimed at building a community of common destiny[12].

\section{“One Belt and One Road” Calls for Deepening Reform across the Country}

\section{An Open Development Strategy to Promote Reform through Opening up}

The third plenary session of the 18th CPC central committee pointed out that "to adapt to the new situation of economic globalization, we must promote mutual promotion of opening up at home and abroad, and promote reform through better combination of bringing in and going global". From this perspective, the development strategy of "One Belt and One Road" is the concrete embodiment of the policy for promoting reform through opening up in China.

Since 1978, China has gone through four tides of reform through opening up. In 1980, the reform and opening up was carried out with the establishment of special economic zones. By actively promoting the opening of the coastal areas to the outside world and learning from market economy countries and regions, domestic reform was promoted. Around 1992, Deng xiaoping's southern tour speech and the establishment of the reform orientation of market economy initiated the second round of opening up to the outside world. This has created a comprehensive opening pattern for coastal, riverfront, border and inland central cities, effectively promoting the transition to market economy. The third round of opening up to the outside world constituted by the accession to the WTO in 2001 essentially means the introduction and absorption of a whole set of rules, constitutions or systems, and also means the creative destruction of the original rules, constitutions or systems [13]. If the first two rounds of opening up focus on the promotion on the surface, then the third round of opening up is a deep adjustment of rules and systems. The implementation of the "One Belt and One Road" strategy can be regarded as the fourth round of opening-up. By opening up to the outside world and deepening domestic reform in an all-round way, it makes preparations for China's deep integration into the global economy in terms of institutional rules and growth momentum, completes the connection between the domestic economy and the international economy, and enables Chinese economy to move from "bringing in " to "going global" (see table 2).

Under this round of open economy development strategy, promoting reform through opening up and promoting development through reform can better solve the sustainable driving force of Chinese economic development. First of all, deep integration into the global economy is the inevitable result of China's increasing external dependence. At present, Chinese economy is increasingly dependent on the market, energy, resources, technology and management experience of the world economy. Attempts to implement a closed economy to achieve sustained growth are no longer possible and complex economic relationships must be 
actively addressed. Second, the growth of the global economy increasingly reflects the role of technological progress and knowledge accumulation. The upgrading of industrial structure and the construction and leading of global value chain must promote enterprises to improve their ability through global production. Third, with the full participation and deep integration of the international economy, it will be a natural process to adapt, integrate, participate and lead the international economic rules. This process must be linked to the development of domestic market rules. A new round of opening up to the outside world will still form a "antidriving mechanism" for comprehensively deepening reform at home. Fourth, only the development thinking and concept of globalization can solve the bottleneck of development and promote the sustainable development of Chinese economy.

Table 2. Four opening strategies since reform and opening up in China

\begin{tabular}{|c|c|c|c|c|}
\hline First & Time & Form and mark & Objective and content & Major achievements \\
\hline Second & $1978-1991$ & $\begin{array}{c}\text { Foreign trade; The third plenary } \\
\text { session of the eleventh central } \\
\text { committee }\end{array}$ & $\begin{array}{c}\text { Introduce competitive mechanism } \\
\text { and foreign advanced technology to } \\
\text { solve poverty }\end{array}$ & Special economic zones, \\
\hline Third & $2001-2012$ & $\begin{array}{c}\text { Introduce foreign capital, 14 } \\
\text { market economy reform } \\
\text { orientation in 1992 }\end{array}$ & $\begin{array}{c}\text { Make up for the shortage of funds } \\
\text { and promote economic } \\
\text { transformation }\end{array}$ & All-around opening up \\
\hline Fourth & $2013-$ & $\begin{array}{c}\text { Foringing in and going global, and } \\
\text { join WTO }\end{array}$ & $\begin{array}{c}\text { Integration into global production, } \\
\text { export orientation, industrial } \\
\text { diversification }\end{array}$ & World processing plant \\
\hline
\end{tabular}

Material source: organised by author

\section{Through Comprehensively Deepening Reform to Better Integrate with the International Economy}

China has made great achievements in implementing the open economy development strategy. However, we should also recognize that the imperfect institutional mechanism and other reasons have caused difficulties in further development and slow response to the institutional rules. First, the industrial upgrading in our country has been blocked. The United States and other developed countries follow the "superior industry transfer" model to dominate the global industrial value chain, dividing the countries into two types. One is the developed countries with the sustained technological innovation capability. One is the following countries[1] without technological innovation capability and be "captured" at the bottom of the value chain [14]. In order to avoid falling into the "low-end lock" in international economic participation, we must not only follow the principle of comparative advantage, but also construct "institutional advantage", and climb and dominate the global value chain through technological progress. Second, market mechanisms have not yet played a decisive role in resource allocation. After joining WTO, China implemented the WTO accession commitment well in the first five-year transitional period. However, after the fiveyear transitional period, the construction of marketization rules slowed down and administrative intervention measures increased. For example, the development of small and medium-sized enterprises, the opening of domestic service industries and monopoly industries to private enterprises still fail to play a good role in the market. For this, the state council issued two "thirty-six articles on the non-public economy development" in 2005 and 2010. 
For another example, in order to attract investment, a large number of non-standard preferential policies have been implemented in land, taxation, environmental supervision and other aspects, which partially offset the central government's unified policy of opening up to the outside world. As a result, a large number of foreign enterprises enjoy "super-national treatment". Third, micro-enterprises cannot fully adapt to the globalization of production and operation. Compared with large transnational corporations, the main problems of Chinese enterprises are: It lacks the strategic thinking and vision of globalization, and lacks the ability to allocate capital, talent, technology, market and other resources globally; Generally speaking, the international operation is at the primary stage, and the organizational framework, marketing mode and management mode are not suitable, and there are no international talents; It has weak research and design capability, low investment in research and development, and lacks core technologies with independent intellectual property rights, etc. [15], so It is urgent to build multinational companies in China. Therefore, the slow progress of domestic marketization reform will inevitably affect the implementation effect of open economy development. It can be said that the implementation of the Shanghai free trade area is the result of "reverse transmission of pressure" in this kind of open policy, that is, the "negative list" management mechanism of international trade and investment is highly consistent with the reform of Chinese administrative examination and approval system.

\section{Balanced Development of Regional Economy and National and Global Value Chain}

The "One Belt And One Road" strategy reflects China's comprehensive opening-up strategy layout in the new era, that is, putting equal emphasis on the direction of opening up to the outside world, and linking land and sea. In view of that strategy of "One Belt And One Road" and open situation in various parts of China, the focus will be on northeast, northwest, southwest, etc. Therefore, actively promoting the construction of "One Belt And One Road" will not only activate the development potential of the central and western regions, but also further unleash the vitality of development, opening up, innovation and creativity. Moreover, it can optimize the regional layout of domestic open economy, realize coordinated development of various regions, and create important strategic opportunities for improving the overall level of the open economy. We believe that the construction of national and global value chain is an effective way to combine domestic development and overseas opening.

First of all, the border areas should not follow the traditional industrialization path, nor should they implement the "two sides out" OEM model of coastal areas. They should adopt the model of product value chain and actively accept the transfer of coastal and inland industries. In this way, development opportunities are not only obtained along the border areas, but also organically linked to the economic development of inland and coastal areas, so as to achieve dynamic balance in regional economic development. Secondly, the national value chain is constructed through balanced regional development and industrial transfer in China, and then the China-led global value chain is constructed through" One Belt And One Road. Under the strategy of "One Belt And One Road", the coastal areas have accelerated their opening up and taken part in international exchanges and international division of labour on a larger scale. In their in-depth foreign cooperation, they can transfer more technology and management experience to the mainland and vacate domestic market for the mainland and border areas. In this way, the development of two markets at home and abroad has provided industrial space for the construction of Chinese industrial value chain. 


\section{Avoid the "Middle-Income Trap" and Improve the Quality of Growth}

The "middle-income trap" was first proposed by the world bank in 2007. It refers to the economy entering the middle-income stage whose further economic growth is locked in by the original growth mechanism, leading to the decline or stagnation of economic growth. It is difficult for per capita national income to break the upper limit of the middle income level. Domestic scholars have two general understandings of this phenomenon. One is to interpret it only from the perspective of growth. For example, Yao zhizhong [16] believes that the "middle-income trap" is actually a growth trap, which is economic growth stagnation or negative growth by absolute standards. By relative standards, the economic growth rate is lower than that of high-income countries, and the gap with developed countries is not convergence, but widening. These two states can be described as being in the "middle income trap". Another view [17] holds that the understanding should be carried out from the perspective of development mode, which means that the development mode meets the bottleneck, which is insufficient to support the economy to realize the leap from the previous factor drive to the efficiency drive and even the innovation drive. First of all, the transformation of economic development pattern meets the obstacle of economic structural transformation. Secondly, there are obstacles to the transformation from extractive institutions to inclusive institutions. In particular, the boundary between the government and the market, the government and the society is not clear, and it is difficult to effectively promote the transformation of the economic development pattern and economic structural transformation. In view of that growth rate, China will not have the worry of "medium income trap", but in case of development, China's "medium income trap" need to be alert. The own deep-seated challenges of declining growth momentum, distorted economic structure, lack of public services, widening income gap, weakened social mobility, serious environmental pollution and tighter resource constraints in China actually highlight the risks of "middle-income trap".

Therefore, how to avoid the "middle-income trap" has put forward the requirement of changing the development mode and deepening the reform comprehensively. This requires high attention to the quality of growth in future economic growth and the transition of economic growth from dependence on factors to dependence on technology and institutions [18]. The internal and external pressure caused by the implementation of "One Belt and One Road "strategy is conducive to the formation of this transformation.

\section{Grasp the Essence of “One Belt and One Road” Development Strategy with "New Normal" Thinking}

\section{Foster Global Thinking and Promote Reform and Development through Opening-up}

From the perspective of current economic aggregate and development stage in China, Chinese economy is in a critical period of transition from middle income to high income. Transformation of development model, creation of growth impetus and internalization of institutional rules, these fundamental problems still need to be addressed through the dividends of opening and reform.

The problems that Chinese economic development is facing can be summarized as the market, technology and system. Market expansion can be solved by industrial upgrading and product creation. Resource shortage and environmental constraints can be overcame through technological advances and trade investment. Technological advances and the use of trade rules must be addressed by institutional guarantee. Therefore, the internalization of market 
economy rules is the key factor that needs to be fundamentally solved through reform. Where does the impetus for reform come from? It comes from the pressure of development, and from the pressure of international competition. When the economy reaches a certain scale, it will naturally put forward the demand for the market. Expanding domestic demand is a direct source of market release. However, the expansion of the domestic market is closely linked to the upgrading of the industrial structure Without the upgrading of industrial structure, the expansion of domestic demand market will encounter a bottleneck [19]. The upgrading of industrial structure is carried out in conjunction with the digestion of excess capacity and the transformation of development modes. This raises the demand for foreign markets and the problem of international industrial transfer Therefore, the current problem is to obtain the space for economic growth through the transfer of foreign industries, which is the root of promoting reform and development through opening up. If the previous opening strategy was "through capital introduction and industrial transfer, to obtain technological progress and promote economic growth", then the new opening strategy is "through foreign investment and industrial transfer, to promote technological progress and economic growth".

\section{Change the Development Way and Improve Economy Quality}

The new normal of economic development indicates that Chinese economy has entered a period of adjustment from high growth to medium-high growth. The mode of economic development has changed from dependence on factors to improvement of quality of technological progress. Paying attention to knowledge accumulation, technological progress, industrial upgrading, reconstruction of micro subjects and stable economic operation are the key contents to improve Chinese economic quality. All development policies and economic strategies should be implemented around these core tasks, which naturally includes both "One Belt and One Road" strategy and is the key to "One Belt and One Road" strategy. However, due to the influence and constraint of past development experience, it is easy to go on the old road of traditional development in the process of implementation. For example, some local governments understand "One Belt and One Road" as a new measure of policy and tax incentives, a new opportunity for investment in projects, rather than as a new opportunity for opening up to the outside world and promoting reform, so as to plan large-scale infrastructure investment projects. In this way, it is possible to form a new round of similar industries in provinces and regions along the way and lack complementary investment boom in infrastructure [12]. These are not out of thin air, and they are already evident in the development goals of local governments. For example, the debate between the starting point and the scope of One Belt and One Road in various regions is actually a meaningless conceptual hype. The "leading strategy" proposed by different regions has the suspicion of domestic regional competition, such as the starting point and bridgehead of the silk road economic belt proposed by Shaanxi province. Xinjiang proposed to build the main force and vanguard of the silk road economic belt. Gansu proposed to build the key junction of the silk road economic belt. Guangxi proposed to build a new gateway core hub of the 21st century maritime silk road [20], etc.

\section{Respect Market Rules and Promote Institutional Development}

System quality is one of the sources of comparative advantage. China's foreign investment and industrial transfer and leading global value chain must have competitive institutional rules. Such rules must be global governance rules based on market investment, trade, exchange rate, environment, policies and other relevant content, and corporate governance rules based on 
global production and operation of micro subjects. Objectively speaking, China needs to make greater efforts in this regard. At present, the international investment and industrial transfer of Chinese capital are still based on the advantages of manpower, not technology and management. It is more about foreign engineering investment and low-end production in manufacturing, rather than high-tech transfer and marketing branding. The business model of global value chain makes international economic communication more and more reflect the content of service trade, which involves complex market contract, trading rules and consultation mechanism at any time. Generally, the more advantageous the system rules, the more advantageous the position in international economic exchanges. The more mature the legal system and the better the contract system, the easier it is to implement high value-added activities in the global value chain [21]. The aim of the "One Belt and One Road" strategy is to integrate Chinese economy more deeply into the global economy. If we cannot have institutional advantages in the operation of the market mechanism, it is difficult to gain dominant power in international economic relations. Therefore, it is necessary to create the development space for domestic development mode transformation and industrial structure upgrading through the "One Belt And One Road" opening strategy. By promoting reform through opening up and creating an international, market-oriented and legalized business environment, the market can play a decisive role in resource allocation, get out institutional advantages and enhance soft power.

\section{Rely on Global Value Chain, Drive Knowledge Accumulation and Technological Progress}

The contemporary economic development shows that technological progress is the sustained power of economic growth. The production of global value chain is also based on technological leadership, business experience and institutional advantages. Therefore, knowledge accumulation and technological progress are playing an increasingly important role in economic development, which is the main source of a country's economic competitiveness and the main sign of high economic quality. From a worldwide perspective, the industries of emerging economy, whether traditional industries, emerging industries or even strategic industries, are not advanced and already exist in developed countries [21]. In this respect, we must correct our attitude, recognize our differences, and find our own direction. We should regard "One Belt and One Road" as the challenge and opportunity of reentering the WTO. Of course, in the previous round of open economy, China has achieved rapid development by utilizing international technology transfer and industrial transfer. However, in the future development, the bottleneck of technology upgrading is getting bigger and bigger. In the global value chain, we can only follow the advanced enterprises of developed countries. As is known to all, in order to maintain the technology leading level, leading enterprises not only control the core technologies, designs, brands and standards of the global value chain, but also control most of the learning, innovation, knowledge transfer and industrial upgrading activities [5]. Therefore, in order to get rid of the dilemma of "lowend lock" in the global value chain, it is necessary to build a domestically led global value chain, which requires the accumulation and pursuit of knowledge capital and technological innovation. "One Belt and One Road” strategy gives us a good opportunity and development space. When we transfer industries along the routes and surrounding countries, we should pay attention not only to interconnection of the hardware construction of these global value chains, but also to the software construction of knowledge capital. We should accumulate the climbing and leadership of global value chain from the aspects of development strategy, 
institutional rules, human capital, research and development, management experience and so on.

\section{References}

[1] Dong xiaojun. International transfer to reduce overcapacity: five global waves, two models and China exploration [J]. Economic research reference, 2014, (55):3-18.

[2] Zhang mingzhi,Liang hongji. The industrial control power in the reconstruction of global value chain -- from the perspective of the change of the world wealth distribution control mode [J]. World economy and politics BBS,2015,(1):1-23.

[3] Michel Ruta, Saito Meixiang. Global value chain [J]. International economic review, 2014,(5):155-158.

[4] Sheng bin, Chen shuai. How global value chain changes trade policy: the influence and enlightenment on industrial upgrading [J]. International economic review,,2015,(1):85-97.

[5] Liu shiguo, Wu haiying. Global value chain and value-added trade: economic impact, policy implications and statistical challenges [J]. International economic review,2013, (4):8798.

[6] Liu zhibiao. Shifting from global value chain to global innovation chain: new impetus for China's industrial development under the new normal [J]. Academic journal,,2015,(2):5-14.

[7] Zhang youwen. Characteristics of China's open development path -- questioning the "comparative advantage strategy of cheap labor" [J]. Academic journal,2015, (3):74-82.

[8] Lu jinyong, Chen jing, Wang guang. Accelerating the construction of cross-border industrial chain dominated by Chinese transnational corporations [J]. International trade,2015, (4):4-10.

[9] Huang haizhou, Zhou chengjun. Strategic layout of opening to the outside world under the new situation [J]. New finance review, 2013, (3):1-36.

[10] $\mathrm{Xu}$ qingjun. Promoting opening-up with the concept of global value chain [J]. China's foreign trade, 2013, (10):59-61.

[11] Shen xianjie, Xiao jincheng. New situation of international regional economic cooperation and China's "One Belt And One Road" cooperation strategy [J]. Macroeconomic research, 2014, (11):30-38.

[12] Li xiangyang. Build a priority relationship for “One Belt and One Road” [J]. International economic review, 2015, (1):53-63.

[13] Zhang yuyan et al. The 10th anniversary of China's accession to the WTO: summary and prospect [J]. International economic review, 2011, (5):40-83.

[14] Liu zhibiao, Zhang jie. From integration into global value chain to construction of national value chain: strategic thinking on China's industrial upgrading [J]. Academic journal, 2009, (9):59-68. 
[15] Research group of research centre of SASAC. Economic globalization and deepening reform and opening up [J]. Economic research reference, 2012, (3):3-14.

[16] Yao zhizhong. What is the real middle-income trap [J]. International economic review, 2014, (6):75-88.

[17] Tian guoqiang, Chen xudong. How China can overcome the "middle-income trap" -from the perspective of institutional transformation and national governance [J], academic journal, 2015, (5):18-27.

[18] Ren baoping. Quality of economic growth: theoretical interpretation, basic propositions and ethical principles [J]. Academic journal, 2012, (2):63-70.

[19] Liu zhibiao. Strategic concept and implementation mechanism: China's second wave of economic globalization [J]. Academic journal, 2013, (1):88-96.

[20] Yuan xintao. National strategic analysis on the construction of the silk road economic belt and the 21st century maritime silk road [J]. Southeast Asia, 2014, (8):3-8.

[21] Liu shiguo et al. Use global value chain to promote industrial upgrading [J]. International economic review, 2015, (1):64-84. 